\title{
PENEGAKAN HUKUM KETENTUAN PIDANA PASAL 200 UNDANG-UNDANG NOMOR 36 TAHUN 2009 TENTANG KESEHATAN
}

\author{
Tisa Windayani \\ Hukum Pidana, Fakultas Hukum, Unika Atma Jaya Jakarta \\ Jl. Jend. Sudirman Kav 51, Jakarta, 12930 \\ tisa.windayani@atmajaya.ac.id
}

\begin{abstract}
Art 200 of Law no 36/2009 on Health specifies that every person who is intentionally hinder the implementation of exclusive breastfeeding program will be penalized. Despite the existence of this provision, the enforcement of it is still unheard. Mothers are the central subject of this so called exclusive breastfeeding program. This research questioning the cause of the unimplemented art 200, with the focus on the legal culture of the mother as one of the indispensable elements of it's enforcement. It is found that nearly all respondents choose not to use the Art 200, if they are faced with the situation where their rights are violated by spouse, family, and working-related parties. This makes the enforcement become difficult to happen.
\end{abstract}

Keywords: law enforcement of breastfeeding rights, legal culture, breastfeeding rights, art 200 Law no 36/2009

Intisari, Pasal 200 UU No. 36/2009 Tentang Kesehatan mengatur bahwa setiap orang yang dengan sengaja menghalangi pelaksanaan program ASI eksklusif diancam dengan sanksi pidana. Walaupun demikian, penegakan hukum atas pasal ini belum berjalan dengan baik. Di lain pihak ibu menyusui adalah subjek sentral dari pelaksanaan ketentuan ini. Penelitian ini membahas mengenai mengapa penegakan hukum Pasal 200 belum berjalan namun dilihat dari aspek budaya hukum ibu menyusui sebagai elemen penting bagi penegakkan hukum. Kesimpulan penelitian ini adalah bahwa budaya hukum responden ibu menyusui merupakan salah satu factor yang mendasari keputusan responden untuk tidak menggunakan Pasal 200 ketika hak nya dilanggar.

Kata kunci : penegakan hukum hak menyusui, budaya hukum, hak menyusui, Pasal $200 \mathrm{UU}$ No.36/2009

\section{Pendahuluan}

Manfaat dari pemberian ASI bagi bayi sudah banyak dibuktikan melalui berbagai riset. Baik manfaat bagi kesehataan tumbuh kembang bayi secara fisik maupun mental. Hal ini karena ASI mempunyai sifat mudah dicerna dan diserap oleh tubuh bayi, mengandung unsure esensial yang dibutuhkan tubuh bayi, dan sifatnya yang segar, bersih dan aman'. Di Indonesia lapangan hukum pidana ikut memberikan peran guna

\footnotetext{
${ }^{1}$ Sri Handajani ES, Pola Pemberian dan Komposisi Gizi ASI, (Yogyakarta: Bengkel Buku, 2002)
} hlm 29 
memberikan jaminan atas pelaksanaan pemberian ASI. Hal ini terdapat dalam Pasal 200 UU NO. 36/2009 Tentang Kesehatan yang berbunyi:

"Setiap orang yang dengan sengaja menghalangi program pemberian air susu ibu eksklusif sebagaimana dimaksud dalam Pasal 128 ayat (2) dipidana paling lama 1 (satu) tahun dan denda paling banyak Rp 100.000.000 (seratus juta rupiah)"

Pasal tersebut memberikan jaminan dengan cara mengancam sanksi pidana bagi siapa saja yang dengan sengaja menghalangi program pemberian ASI.

Berdasarkan penelusuran data secara pustaka yang dilakukan oleh Peneliti, sampai dengan penulisan ini dilakukan, belum pernah ada tercatat pelanggaran yang diperkarakan secara pidana terhadap ketentuan pidana Pasal 200. Walaupun di lain pihak, beberapa riset menunjukkan dugaan terjadinya penghalangan program pemberian ASI Esklusif, seperti yang dimaksud dalam Pasal 200. Perbuatan tersebut mulai dari halangan yang dilakukan pihak keluarga ataupun halangan yang berasal dari pihak dimana si ibu bekerja. Sebuah penelitian yang dilakukan oleh Griffith menemukan bahwa terdapat aspek tekanan psikologis dari anggota keluarga terhadap ibu menyusui, dimana ibu berusaha menyenangkan anggota keluarga dewasa lainnya dengan memberi makanan tambahan bagi bayi mereka supaya tidak kelaparan ${ }^{2}$. Terkait dengan kondisi pekerjaan ibu terutama pemberian cuti melahirkan yang ternyata berpotensi sebagai penghalang pemberian ASI Eksklusif $^{3}$.

Penelitian dengan topik yang hampir sama adalah Perspektif Kebijakan Hukum Pidana Terhadap Pelaksanaan Program ASI Eksklusif oleh (Studi di Wilayah Hukum Polda Lampung) oleh Debi Silvia Ridzal. Penelitian ini fokus pada hukum pidana sebagai sarana untuk menentukan perbuatan-perbuatan apa saja yang dilarang, kapan dan dalam hal apa larangan itu dapat dikenakan pidana, dan menentukan dengan cara apa pengenaan pidana itu dapat dilaksanakan. Masalah yang dikaji dalam penelitian tersebut adalah bagaimanakah perspektif kebijakan hukum pidana terhadap pelaksanaan program ASI eksklusif dan apa sajakah faktor penghambat pelaksanaan progam ASI tersebut. Hasil peneltian ini adalah bahwa perspektif kebijakan hukum pidana terhadap pelaksanaan program ASI eksklusif ini yaitu bahwa perbuatan-perbuatan yang dilarang dan tidak boleh dilakukan terkait program ASI ini salah satunya tidak menyediakan ruang khusus menyusui (ruang laktasi). Faktor penghambat yang paling dominan adalah faktor undangundang dan faktor masyarakat. Faktor undang-undang seperti tidak jelasnya pihak-pihak mana yang mengawasi program ASI dan faktor masyarakat dalam hal ini ketidaktahuan dan ketidakpahaman masyarakat tentang pentingnya ASI eksklusif, dan kurangnnya keberanian masyarakat untuk melapor kepada pihak berwajib apabila merasa dirugikan dalam hal menjalankan program ASI eksklusif ${ }^{4}$. Perbedaan penelitian ini dengan penelitian yang dilakukan oleh Penulis adalah bahwa penelitian penulis fokus pada

2 Griffith dalam Nurhira Abdul Kadir, Menelusuri Akar Masalah Rendahnya Persentase Pemberian ASI Ekslusif di Indonesia, Jurnal Al Hikmah Vol XV No. 1/2014, hlm 109.

${ }^{3}$ Ibid.

${ }^{4}$ Debi Silvia Ridzal, Perspektif Kebijakan Hukum Pidana Terhadap Pelaksanaan Program ASI

Eksklusif (Studi di Wilayah Hukum Polda Lampung), 2016, hal. 49. http://digilib.unila.ac.id/23602/3/SKRIPSI\%20TANPA\%20BAB\%20PEMBAHASAN.pdf, diunduh pada 11 Januari 2018 
budaya hukum dari ibu menyusui, sedangkan penelitian Debi di atas melihat pada masyarakat yang lebih luas. Responden dalam penelitian ini adalah ibu yang menyusui bayinya (baik secara langsung maupun tidak langsung) selama minimal 3 bulan pertama sejak bayi lahir, berpendidikan minimal S1, dan pernah mendapat edukasi tertang hak menyusui.

Budaya hukum adalah salah satu faktor penting dalam keberhasilan penegakan hukum. Menurut Jimly Asshiddiqie salah satu aspek penting dalam rangka penegakan hukum adalah proses pembudayaan, pemasyarakatan, dan pendidikan hukum (law socialization and law education). Tanpa didukung oleh kesadaran, pengetahuan dan pemahaman oleh para subjek hukum dalam masyarakat, nonsens suatu norma hukum dapat diharapkan tegak dan ditaati ${ }^{5}$. Pendapat lain yang menyatakan bahwa budaya hukum merupakan aspek peting dalam penegakan hukum juga dikemukakan oleh Sudibyo Saleh yang menyatakan bahwa penegakan hukum pada dasarnya harus memperhatikan aspekaspek yang mempengaruhi upaya penegakan hukum tersebut, yaitu meliputi (1) materi hukum (peraturan/perundang-undangan); (2) aparatur penegak hukum (hakim, jaksa, polisi, advokat dan lembaga pemasyarakatan); (3) sarana dan prasarana hukum dan (4) budaya hukum (legal culture) ${ }^{6}$. Seperti telah disingung sebelumnya bahwa pihak yang paling berkepentingan terkait pemberian ASI adalah ibu menyusui. Sehingga tentunya kesadaran hukum dan budaya hukum ibu menyusui menjadi sangat penting dalam rangka penegakkan Pasal 200 UU Kesehatan. Perlu dijelaskan bahwa penelitian ini tidak mengkaji aspek aparatur penegak hukum dan aspek sarana dan prasarana hukum. Penelitian ini focus pada budaya hukum dari ibu menyusui.

Dapat dimaklumi apabila kendala atau hambatan sangat mungkin datang dari pihakpihak di sekeliling ibu menyusui. Tidak jarang ibu menyusui, dalam relasinya dengan pihak-pihak tersebut tidak dapat lepas dari faktor-faktor seperti ketergantungan pada pihak tersebut, hubungan personal yang cukup dekat dan seringkali ibu menyusui memiliki keterikatan secara mental dengan pihak itu, dan berada dalam posisi inferior dalam relasi dengan pihak tersebut. Menyadari fakta itu dan dikaitkan dengan keberadaaan Pasal 200 yang memuat sanksi pidana, maka akan menjadi pertanyaan apakah ibu menyusui,sebagai subjek sentral dari keberhasilan pemberian ASI, dapat menjadi subjek hukum/agen hukum yang dapat berkontribusi dalam penegakan pasal 200 tatkala pelaku dari tindak pidana seperti adalah orang-orang yang berasal dari lingkungan keluarga dan lingkungan kerja, mengingat faktor-faktor yang telah dijelaskan di atas.

Pentingnya peran ibu menyusui dalam penegakan Pasal 200 dipengaruhi oleh sifat dari perbuatan pidana yang diatur di dalam Pasal tersebut. Perbuatan pidana dimaksud mencakup pelanggaran atas kewajiban dari berbagai pihak di sekeliling ibu menyusui untuk menyediakan waktu dan fasilitas khusus bagi ibu untuk memberikan ASI eksklusif

5 Prof. Dr. Jimly Asshiddiqie, S.H "Pembangunan Hukum Dan Penegakan Hukum Di Indonesia", Disampaikan pada acara Seminar "Menyoal Moral Penegak Hukum" dalam rangka Lustrum XI Fakultas Hukum Universitas Gadjah Mada. 17 Februari 2006.

6 Sudibyo Saleh, Komitmen Supremasi Hukum di tengah Kemajuan Masyarakat Indonesia, Makalah yang disampaikan dalam Dialog Nasional Profesional Aparat Penegak Hukum dalam Pelaksanaan di tengah Masyarakat yang Bersih dan Berwibawa, Jakarta, 11 Oktober 2004, hlm. 56 
atau memerah ASI. Pelanggaran terhadap kewajiban (yang merupakan hak yang harus didapatkan oleh ibu menyusui) adalah perbuatan yang memiliki sifat sedemikian rupa sehingga sangat mungkin tidak dapat diketahui oleh aparat penegak hukum tanpa adanya pelaporan dari ibu menyusui sendiri, ataupun tanpa adanya keterlibatan ibu menyusui dalam bentuk lainnya dalam rangkaian proses penegakan hukum. Terutama apabila perbuatan pidana itu terjadi dalam lingkup keluarga ataupun lingkungan kerja. Dalam dua lingkup tersebut, dapat dipahami bahwa aparat penegak hukum memiliki akses yang sangat terbatas ataupun bahkan tidak memiliki akses sama sekali, yang membuat aparat tidak mungkin berinisiatif memulai proses penegakan hukum tanpa adanya informasi dari ibu menyusui ataupun pihak lainnya. Itulah sebabnya, walaupun delik dalam Pasal 200 adalah delik biasa dan bukan delik aduan, peran dari ibu menyusui dalam penegakannya menjadi vital.

Penelitian ini focus pada pihak keluarga dan lingkungan tempat kerja. Hal ini karena kedua pihak tersebut cukup banyak mempengaruhi keberhasilan ataupun kegagalan dalam pemberian ASI eksklusif. Menurut IDAI, faktor yang menghambat keberhasilan menyusui pada ibu bekerja adalah pendeknya waktu cuti kerja, kurangnya dukungan tempat kerja, pendeknya waktu istirahat saat bekerja (tidak cukup waktu untuk memerah ASI), tidak adanya ruangan untuk memerah ASI, pertentangan keinginan ibu antara mempertahankan prestasi kerja dan produksi $\mathrm{ASI}^{7}$. Masalah pada penelitian ini adalah: Mengapa penegakan hukum ketentuan pidana dalam Pasal 200 UU No. 36 Tahun 2009 belum terlaksana ? Seperti telah dijelaskan di atas bahwa peneltian ini focus pada budaya hukum ibu menyusui sebagai salah satu aspek dalam penegakan hukum. Sehingga, untuk menjawab masalah penelitian di atas, maka secara lebih khusus diteliti hal-hal berikut yaitu : a). Bagaimana sikap ibu menyusui terhadap ketentuan pidana Pasal 200 UU No. 36/2009?; dan b). Bagaimana budaya hukum dari ibu menyusui untuk berpartisipasi dalam penegakan ketentuan pidana dalam Pasal 200 UU No. 36/2009?

\section{Metode Penelitian}

Penelitian ini adalah penelitian yuridis-empiris. Metode penelitian yuridis-empiris pada dasarnya merupakan penggabungan antara pendekatan hukum normatif dengan adanya penambahan berbagai unsur empiris. Bentuk penelitian ini adalah penelitian deskriptif yaitu penelitian yang bertujuan untuk menggambarkan secara cermat karakteristik dari fakta-fakta (individu, kelompok atau keadaan), dan untuk menentukan frekuensi sesuatu yang terjadi ${ }^{8}$. Analisis yang digunakan adalah analisis kualitatif. Tujuan analisis data kualitatif adalah mencari makna dibalik data yang diperoleh dari pengakuan subjek ${ }^{9}$.

Jenis data yang digunakan adalah:

7 IDAI, “Suskes Menyusui Saat Bekerja”, http://idai.or.id/public-articles/klinik/asi/suksesmenyusui-saat-bekerja-2.html, diakses pada 10 Mei 2017

${ }^{8}$ Rianto Adi, Metode Penelitian Sosial dan Hukum, (Jakarta: Granit, 2004), hlm. 58

9 H. Moh. Kasiram, Metodologi Penelitian Kualitatif-Kuantitaif, (Malang: UIN Maliki Press, 2010), hlm. 355 
a) Data primer, penelitian ini mengambil data dari responden ibu menyusui. Metode pengumpulan data yang digunakan adalah salah satu dari metode non-probability sampling yaitu purposive sampling yaitu pengambilan sampling tanpa berdasarkan populasi dan dengan menetapkan ciri tertentu ${ }^{10}$. Adapun ciri atau karakteristik dari ibu menyusui yang ditetapkan adalah: ibu yang menyusui bayinya (baik secara langsung maupun tidak langsung) selama minimal 3 bulan pertama sejak bayi lahir, berpendidikan minimal S1, dan pernah mendapat edukasi tentang hak menyusui. Penjelasan tentang alasan pemilihan karakteristik tersebut dijelaskan pada bagian pembahasan. Teknis pengumpulan data dilakukan dengan cara penyebaran kuesioner maupun wawancara langsung.

b) Data sekunder, dalam penelitian ini digunakan data sekunder yang terdiri dari:

i) Bahan hukum primer, semua peraturan perundang-undangan yang terkait dengan topik penelitian ini antara lain; UUD 1945, UU No. 36 Tahun 2009 Tentang Kesehatan, PP N0. 33 Tahun 2012 Tentang Pemberian Air Susu Ibu Eksklusif, dan Peraturan Menteri Kesehatan No. 15 Tahun 2013 Tentang Tentang Tata Cara Penyediaan Fasilitas Khusus Menyusui dan/atau Memerah Air Susu Ibu.

ii) Bahan hukum sekunder, teori dan pendapat ahli, hasil penelitian dan pemikiran terkait topik penelitian ini.

\section{Hasil dan Pembahasan}

Terlebih dahulu Penulis akan memaparkan dasar- dasar yang menjadi kerangka teori yang digunakan dalam penelitian ini.

\section{Ketentuan Pidana Terkait Hak Menyusui}

Penggunaan hukum pidana untuk memberikan pengaturan tentang sesuatu hal (perbuatan) dalam suatu masyarakat tentunya harus memperhatikan sifat dan hakekat hukum pidana itu sendiri, disamping menjamin kepentingan pihak yang terkait (khususnya ibu menyusui) dan bahkan seharusnya dapat menjawab kebutuhan kelompok itu. Hak menyusui adalah hak yang dilindungi oleh hukum. UU kesehatan menyatakan bahwa setiap bayi yang dilahirkan berhak mendapatkan ASI Ekskusif. Dan ASI dimaksud diharapkan berasal dari ibu si bayi, kecuali si ibu tidak dapat memberikan ASI dikarenakan hal-hal yang juga telah ditentukan dalam UU Kesehatan dan peraturan pelaksananya. Terkait aturan pidananya salah satu terdapat dalam Pasal 200, yang merujuk pada Pasal 128 ayat (2). Adapun bunyi Pasal 128 adalah sebagai berikut:

(1) Setiap bayi berhak mendapatkan air susu ibu eksklusif sejak dilahirkan selama 6 (enam) bulan, kecuali atas indikasi medis.

(2) Selama pemberian air susu ibu, pihak keluarga, Pemerintah, pemerintah daerah, dan masyarakat harus mendukung ibu bayi secara penuh dengan penyediaan waktu dan fasilitas khusus.

(3) Penyediaan fasilitas khusus sebagaimana dimaksud pada ayat (2) diadakan di tempat kerja dan tempat sarana umum.

\footnotetext{
${ }^{10}$ Rianto Adi, Op.cit, hlm 111.
} 
Adalah hal yang sangat logis untuk menyandarkan pemikiran bahwa dengan diakuinya hak bayi atas ASI Eksklusif maka segala aktivitas yang mendukung hak tersebut, termasuk kepentingan ibu untuk menyusui, pun harus dilindungi. Hal ini sejalan dengan pendapat Hans Kelsen yang antara lain menyatakan bahwa "Hak-hak hukum tidak akan ada sebelum hukum itu ada. Definisi hak hukum sebagai kepentingan yang dilindungi hukum, atau kehendak yang diakui, secara samar-samar menyatakan suatu pemahaman terhadap fakta ini........Hak ini dibuat menjadi hak hukum pertama-tama dengan jaminan dari peraturan hukum." 11

Selanjutnya pada bagian yang lain dalam pembahasan hak hukum Kelsen menyatakan "Pembuat undang-undang menganggap bahwa orang mempunyai kepentingan-kepentingan tertentu di bawah kondisi tertentu, dan pembuat undang-undang bermaksud melindungi sebagian dari kepentingan ini...oleh sebab itu, hak mesti terdapat bukan pada kepentingan yang dianggap seperti itu melainkan pada perlindungan hukum. Perlindungan dari tipe kepentingan yang diberikan oleh pembuat undang-undang adalah berupa penetapan peraturan-peraturan hukum menyangkut kepentingan tertentu" 12 . Terkait dengan ASI Eksklusif, maka kepentingan ibu untuk memenuhi hak bayinya itulah yang menurut teori Hans Kelsen melahirkan hak hukum yang dimaksudkan untuk melindungi kepentingan tersebut. Penggunaan hukum pidana disini tentunya melahirkan implikasi yang sejiwa dengan sifat dari hukum pidana itu sendiri, yaitu adanya ancaman sanksi yang berat di samping adanya campur tangan negara dalam pelaksanaan ketentuan itu. Walaupun tindak pidana dengan sengaja menghalangi program pemberian ASI Eksklusif seperti yang diatur di dalam Pasal 200 diancam dengan sanksi pidana maksimal 1 tahun, dan denda maksimal $R p$ 100.000.000 (seratus juta rupiah), tetaplah merupakan sanksi pidana yang apabila dijatuhkan pada seseorang akan menimbulkan konsekuensi tertentu yang sangat berbeda dengan sanksi pada ranah hukum lain misalnya ganti kerugian pada hukum perdata atau sanksi administratif lainnya, pada orang tersebut.

Kewajiban pengurus tempat kerja dan penyelenggaran tempat umum untuk menyediakan fasilitas khusus kembali ditegaskan dalam Pasal 30 Peraturan Pemerintah No. 33/2012 Tentang Pemberian ASI Eksklusif dan Pasal 3 Permenkes No. 15/2013 Tentang Tata Cara Penyediaan Fasilitas Khusus Menyusui dan/atau Memerah Air Susu Ibu. Sedangkan kewajiban bagi pengurus tempat kerja untuk memberikan waktu dan kesempatan untuk memberikan ASI eksklusif pada bayi atau memerah ASI selama waktu bekerja di tempat kerja diatur di dalam Pasal 34 PP No.33/2012 dan Pasal 3 ayat (2) dan Pasal 6 ayat (1) Permenkes No. 15/2013. Terkait dengan definisi fasilitas khusus, telah diberikan dalam Pasal 1 Permenkes No. 15/2013 yang berbunyi : Fasilitas Khusus Menyusui dan/atau Memerah ASI yang selanjutnya disebut dengan Ruang ASI adalah ruangan yang dilengkapi dengan prasarana menyusui dan memerah ASI yang digunakan untuk menyusui bayi, memerah ASI, menyimpan ASI perah, dan/atau konseling menyusui/ASI. Berdasarkan logika hukum, maka dapat disimpulkan bahwa unsur fasilitas khusus pada Pasal 200 seyogyanya merujuk pada penjelasan dalam kedua peraturan pelaksana tersebut.

\footnotetext{
${ }^{11}$ Hans Kelsen, Teori Umum Tentang Hak dan Negara, (Bandung: Nusa Media, 2011 ), hlm. 116

${ }^{12} \mathrm{Ibid}$, hlm 117-118
} 
Dari serangkaian aturan yang mengatur tentang hak yang dilindungi sanksi pidana, dapat disimpulkan sebagai berikut, a). bahwa sesuai dengan bunyi Pasal 200, hak ibu menyusui yang dilindungi dengan hukum pidana adalah hak untuk diberikan oleh waktu dan fasilitas khusus; b). bahwa kewajiban untuk menyediakan waktu dan fasilitas khusus tersebut dibebankan pada keluarga, Pemerintah, Pemerintah Daerah dan masyarakat. Dalam hal ini tempat kerja dan tempat umum termasuk dalam kelompok masyarakat. c). bahwa berdasarkan logika hukum maka definisi waktu dan fasilitas khusus dalam Pasal 200 merujuk pada PP No. 33/2012 dan Permenkes 15/2013.

\section{Budaya Hukum}

Berbicara tentang budaya hukum tidak akan dapat diepaskan dari pembahasan tenang sistem hukum. Hal ini karena budaya hukum atau legal culture adalah merupakan bagian dari sistem hukum. Oleh karena itu dalam sub baian ini pun pem ahasan budaya hukum dipaparkan dalam kerangka keberadaan budaya hukum sebagai bagian dari sistem hukum. Ide tentang suatu sistem hukum tidak lagi sekedar seperangkat aturan yang tidak saling berhubungan, melainkan suatu kesatuan ${ }^{13}$. Hart memandang terdapat dua syarat minimum yang diperlukan dan mencukupi untuk eksistensi suatu sistem hukum ${ }^{14}$ :

a. pertama, aturan-aturan perilaku yang valid menurut kriteria validitas tertinggi harus secara umum dipatuhi.

b. kedua, aturan pengakuan tersebut harus menspesifikasikan kriteria-kriteria validitas hukum dan aturan perubahan serta ajudikasi, harus secara efektif diterima sebagai standar umum perilaku resmi para pengemban hukum.

Lebih lanjut dalam penjelasannya dinyatakan, syarat pertama hanya perlu dipenuhi oleh individu warga. Mereka dapat mematuhi untuk bagiannya sendiri dengan motif apapun, karena dalam masyarakat yang sehat selalu diterima adanya standar umum perilaku dan kewajiban yang harus dipatuhi, atau bahkan kewaiban ini dapat dilacak pada kewajiban yang lebih umum, yaitu menghormati konstitusi ${ }^{15}$.

Mengenai konsep sistem hukum, hamper semua ahli dan pemikir hukum mengakui konsep sistem hukum yang dikemukakan oleh Lawrence Friedman. Inti dari pemikirannya kurang lebih adalah bahwa sistem hukum meliputi sebagai berikut ${ }^{16}$ :

1. Struktur hukum (legal structure)

Struktur hukum adalah komponen struktural atau organ yang bergerak didalam suatu mekanisme, baik dalam membuat peraturan, maupun dalam menerapkan atau melaksanakan peraturan. Struktur sebuah sistem adalah kerangkan badannya, ia adalah bentuk permanennya, tubuh institusional dari sistem tersebut. Struktur terepresentasi antara lain dalam hal-hal seperti jumlah hakim, yurisdiksi pengadilan, dan orang-orang yang terkait dengan berbagai jenis pengadilan.

2. Substansi hukum (legal substance)

\footnotetext{
${ }^{13}$ Muchamaad Ali Safa'at, Konsep Hukum HL.A Hart, (Jakarta: Konstitusi Pers, 2016), hlm. 95.

${ }^{14}$ Ibid hlm 122.

${ }^{15}$ Ibid, hlm 123.

${ }^{16}$ Lawrence M. Friedman, Sistem Hukum ; Perspektif Ilmu Sosial(The Legal System ; A Social Science Perspective), Bandung: Nusa Media, 2015, hlm 15-17
} 
Substansi hukum adalah produk dari struktur hukum, baik peraturan yang dibuat melalui mekanisme struktur formal atau peraturan yang lahir dari kebiasaan. Substansi tersusun dari peraturan-peraturan dan ketentuan-ketentuan mengenai bagaimana institusi-institusi itu harus berperilaku.

3. Budaya hukum (legal culture)

Budaya hukum adalah nilai, pemikiran, serta harapan atas kaedah atau norma dalam kehidupan sosial masyarakat. Kultur hukum adalah elemen sikap dan nilai social. Kultur hukum mengacu pada bagian-bagian yang ada pada kultur umum - adat kebiasaan, opini, cara bertindak dan berpikir - yang mengarahkan kekuatan - kekuatan social menuju atau menjauh dari hukum dan dengan cara-cara tertentu.

Terkait peran budaya hukum (legal culture), dalam penjelasannya dikatakan bahwa struktur dan substansi hukum adalah komponen-komponen riil dari sebuah sistem hukum, tetapi semua itu paling jauh hanya merupakan cetak biru atau rancangan, bukan sebuah mesin yang bekerja ${ }^{17}$. Gagasan dasarnya adalah bahwa nilai-nilai dan sikap-sikap ketika diterjemahkan menjadi tuntutan akan menghidupkan mesin sistem hukum itu menjadi bergerak atau, sebaliknya, akan menghentikannya di tengah jalan ${ }^{18}$. Ahli lain yang mencoba mendefinisikan budaya hukum adalah Poh Ling Tan. Budaya hukum menurutnya adalah: " $a$ set of social traditions, attitudes and expectations concerning the law, a legal profession and an independent judiciary, together with a respect for these, and internalization of law-abidingness and of legal attitudes, procedures and ways of looking at things..."

Hal-hal yang dimunculkan dalam budaya hukum sangat tergantung setidaknya pada dua hal yakni: a) ketentuan hukum yang ada; b) bentuk penegakkan hukum yang dijalankan; Kedua hal ini pada akhirnya memberikan warna yang kental mengenai bagaimana persepsi masyarakat terhadap hukum dan penegakkannya. Pada akhirnya persepsi ini dimanifestasikan melalui sikap dan perilaku mereka dalam kaitannya dengan hukum ${ }^{20}$. Budaya hukum mengandaikan kesadaran menjadikan hukum sebagai life-world, yakni hukum sebagai jaringan sistem nilai yang merefleksikan ideal hidup masyarakat ${ }^{21}$. Proses internalisasi hukum yang pada gilirannya menciptakan kebiasaan mematuhi hukum menuntut beberapa prakondisi berikut ${ }^{22}$ :

1) perlu kemampuan semua pihak melihat masyarakat sebagai sebuah sistem kerja sama sosial yang saling menguntungkan. Untuk itu dituntut keberanian mentransedensi diri untuk kemudian menempatkan hukum sebagai budaya publik yang memfasilitasi hak dan kewajiban semua pihak secara fair.

2) perlu dipastikan bahwa setiap anggota masyarakat mengakui dan de facto tunduk pada hukum yang sama .

\footnotetext{
${ }^{17}$ Ibid hlm 16

${ }^{18} \mathrm{Ibid}$, hlm 17

${ }^{19}$ Poh Ling Tan (1997) dalam Harkristuti Harkrisnowo, Menjalani Masa Transisi-Mungkinkah Hukum Sebagai Panglima, Jurnal Studi Indonesia, Vol 10 No. 1, 2000, hlm 4-5

${ }^{20}$ Harkristuti Harkrisnowo, Loc., Cit.

${ }^{21}$ Andre Ata Ujan, Membangun Budaya Hukum, Requisitoire -Law Enfrocement and Jusctice Magazine, Vol 20 Tahun 2012, hlm 1.

22 Ibid.
} 
3) hukum tidak boleh bertentangan dengan ideal hidup masyarakat dimana hukum tersebut berlaku. Hukum harus menjadi pranata yang memfasilitasi ideal hidup masyarakat tanpa harus berkompromi dengan nilai-nilai sosial yang kontroversial dari sisi moral.

4) diperlukan pejabat publik yang mampu menjadi animator dan lokomotif berkembangnya budaya hukum.

\section{Budaya Hukum dalam Kerangka Penegakan Hukum}

Sesuai dengan judul penelitian ini, pembahasan berada dalam kerangka penegakkan hukum pidana. Menurut Satjipto Rahardjo penegakan hukum adalah merupakan satu usaha untuk mewujudkan ide-ide dan konsep-konsep menjadi kenyataan. Penegakan hukum adalah suatu proses untuk mewujudkan keinginan-keinginan hukum menjadi kenyataan. Keinginan-keinginan hukum adalah pikiran-pikiran badan pembuat undangundang yang dirumuskan dalam peraturan-peraturan hukum ${ }^{23}$. Penegakan hukum pada dasarnya harus memperhatikan aspek-aspek yang mempengaruhi upaya penegakan hukum tersebut, yaitu meliputi (1) materi hukum (peraturan/perundang-undangan); (2) aparatur penegak hukum (hakim, jaksa, polisi, advokat dan lembaga pemasyarakatan); (3) sarana dan prasarana hukum dan (4) budaya hukum (legal culture) ${ }^{24}$. Penegakkan hukum merupakan upaya yang dilakukan untuk menjadikan hukum, baik dalam arti formil yang sempit maupun dalam arti materiil yang luas, sebagai pedoman perilaku dalam setiap perbuatan hukum, baik oleh para subjek hukum yang bersangkutan maupun oleh aparatur penegak hukum ${ }^{25}$. Lebih lanjut dikatakan bahwa dalam arti luas, proses penegakan hukum itu melibatkan semua subjek hukum dalam setiap hubungan hukum ${ }^{26}$. Dari pendapat tersebut, maka ibu menyusui termasuk subjek yang berperan dalam penegakan ketentuan pidana dalam Pasal 200 dan Pasal 201 UU Kesehatan.

Kaitan antara budaya hukum (kultur hukum) dan penegakkan hukum juga tersirat dalam pemikiran Friedman dalam elaborasinya tentang budaya hukum. Pada tulisannya Friedman memberikan contoh tentang perceraian, kemudian memaparkan bahwa, kultur hukum juga bisa mempengaruhi tingkat penggunaan pengadilan, yakni sikap mengenai apakah akan dipandang benar atau salah, berguna atau sia-sia bila kita pergi ke pengadilan; hal tersebut akan mempengaruhi keputusan untuk mengusahakan perceraian formal $^{27}$. Sebagian juga bersikap masa bodoh terhadap hak-hak mereka atau takut menggunakannya. Nilai-nilai dalam kultur umum juga akan sangat mempengaruhi tingkat penggunaan; apa yang akan dipikirkan atau dikatakan para kerabat mengenai perceraian, efeknya pada anak-anak, keengganan religious dan moral ${ }^{28}$.

Friedman juga membedakan kultur hukum menjadi 2, yaitu ${ }^{29}$ :

a. kultur hukum eksternal, adalah kultur hukum yang ada pada populasi umum, dan;

23 Satjipto Rahardjo, Penegakan Hukum, Suatu Tinjauan Sosiologis, (Yogyakarta: Genta Publishing, , 2009) hlm 24

${ }^{24}$ Sudibyo Saleh, Op.cit, hlm. 5-6

25 Jimly Asshiddiqie, Op.cit hlm 1-2.

${ }^{26}$ Ibid.

${ }^{27}$ Lawrence Friedman, Op cit. hlm 18

${ }^{28}$ Loc. cit

${ }^{29}$ Ibid. hlm 292 
b. kultur hukum internal, adalah kultur hukum para anggota masyarakat yang menjalankan tugas-tugas hukum yang terspesialisasi.

Friedman kemudian mengaitkan fungsi kedua kultur hukum dengan konsep tuntutan kepada sistem hukum yang dicontohkan dengan hal-hal mulai dari dokumen habeas corpus $^{30}$, sebuah surat kepada kongres, sebuah teriakan minta bantuan kepada polisi di jalan gelap di malam hari ${ }^{31}$. Selanjutnya yang terkait dengan penegakkan hukum adalah dikatakan bahwa apa yang menggerakan proses hukum adalah tuntutan kepada sistem. Kepentingan harus diubah menjadi tuntutan; sikap-sikap dan perilaku yang merupakan bagian dari kultur hukum eksternal harus diproses agar sesuai dengan kultur hukum internal, karena "tekanan social"yang ada di awing-awang bukan termasuk tuntutan kepada sistem hukum, kecuali hal itu dikomunikasikan kepada pelaku hukum seorang hakim, seorang anggota legislative, seorang pengacara ${ }^{32}$.

Budaya hukum eksternal juga dipengaruhi oleh nilai dari lingkungan social, sehingga perilaku yang secara formal bisa jadi merupakan hal yang illegal, tetapi secara social disetujui ${ }^{33}$. Dalam menjelaskan hal ini, Friedman memakai contoh korupsi dan kolusi, dimana ia menjelaskan ketika seorang personil kantor diminta oleh saudaranya untuk memberikan kepadanya jabatan juru tulis, kuatnya ikatan kekerabatan membuat ia sulit menolak, karena penolakan akan dipandang sebagai pengkhianatan terhadap loyalitas keluarga. Dan di sisi lain ikatan terhadap egara lemah ${ }^{34}$. Penjelasan tersebut menunjukkan dalam hal ini (penegakan hukum) korupsi mengandung unsur-unsur structural sekaligus kultural. Bilamana legitimasi sistem hukum formalnya rendah, korupsi akan tambah subur. Begitu mucul, korupsi tetap akan sulit untuk dicabut, karena korupsi menjadi cara bertindak yang dimaklumi ${ }^{35}$. Lebih lanjut, Friedman juga menekankan bahwa untuk mengajukan sebuah usulan hukum, sebuah pihak harus mengubah kepentingannya menjadi tuntutan dan mengungkapkan tuntutan itu sebagai klaim atas hak atau senketa fakta. Ini mungkin hanya merupakan langkah formal, tetapi kultur menghendaki itu ${ }^{36}$.

\section{Budaya Hukum Ibu Menyusui}

Pada bagian sebelumnya telah dipaparkan mengenai penegakkan hukum dan budaya hukum. Seperti telah dikemukakan pada Bab 1 bahwa penelitian ini focus pada aspek budaya hukum dari ibu menyusui sebagai salah satu unsur penting dalam penegakan Pasal 200 UU No. 36 Tahun 2009. Dan dari apa yang dikemukakan oleh Friedman terkait kultur hukum eksternal dapat dikatakan bahwa kultur hukum ibu menyusui dapat termasuk dalam kultur hukum eksternal itu karena ibu menyusui termasuk dalam populasi umum. Dan kultur hukum eksternal tersebut ikut mempengaruhi penegakkan hukum (dalam pemikiran Friedman dipakai istilah tuntutan pada sistem hukum). Sehingga dapat

\footnotetext{
${ }^{30}$ Dalam https://thelawdictionary.org/habeas-corpus/, diartikan sebagai : a variety of writs, having for their object to bring a party before a court or judge.

${ }^{31}$ Lawrence Friedman, Op cit hlm. 292

${ }^{32}$ Loc cit

${ }^{33} \mathrm{Ibid}$, hlm 293.

${ }^{34}$ Ibid, hlm 294

${ }^{35}$ Loc cit

${ }^{36} \mathrm{Ibid}, \mathrm{hlm} 296$
} 
dikatakan bahwa kultur hukum ibu menyusui ikut mempengaruhi penegakkan hukum dari Pasal 200 yang berkaitan dengan keberadaan ibu menyusui. Selain itu, sesuai yang dikemukakan oleh Prof Jimly Asshidique, yang telah dikemukakan di atas, penegakkan hukum sangat dipengaruhi oleh subjek yang terkait di dalamnya. Dalam hal ini, ibu menyusui merupakan subjek yang terkait dalam penegakan hukum Pasal 200.

Berdasarkan logika tersebut penting untuk memformulasikan, untuk keperluan penelitian ini, tentang apa yang dimaksud dengan budaya hukum ibu menyusui. Dari apa yang telah dijelaskan di atas, terdapat beberapa aspek yang dapat diambil untuk memberikan batasan mengenai budaya hukum ibu menyusui dalam kerangka penegakkan hukum Pasal 200. Berdasarkan pendapat para ahli, maka dapat dibangun konsep dan batasan atas budaya hukum ibu menyusui sebagai berikut:

a. ibu menyusui termasuk dalam populasi umum, dimana disitulah terdapat yang dinamakan kultur hukum eksternal

b. budaya hukum ibu menyusui meliputi nilai, pemikiran, sikap serta harapan dari ibu menyusui atas Pasal 200 dalam konteks kehidupan social masyarakat.

c. budaya hukum ibu menyusui juga mengacu pada bagian-bagian yang ada pada kultur umum - adat kebiasaan, opini, cara bertindak dan berpikir - yang mengarahkan pada keputusan untuk menuju atau menjauh dari hukum dalam hal ini Pasal 200. Bagian inilah yang terkait dengan penegakan hukum Pasal 200. Kultur hukum dapat mempengaruhi tingkat penggunaan pengadilan. Dengan kata lain, kultur hukum ibu menyusui yang meliputi nilai, pemikiran, sikap, dan harapan serta kultur umum di sekelilingnya akan mempengaruhi keputusan dari ibu menyusui untuk menggunakan pengadilan atau tidak melalui mekanisme tuntutan pada sistem hukum.

d. kultur umum di sekeliling ibu menyusui adalah seperti yang dimaksud oleh Friedman yaitu perilaku yang secara formal bisa jadi merupakan hal yang illegal, tetapi secara social disetujui.

\section{Gambaran Umum Data Penelitian}

Dalam rangka menjawab masalah penelitian, telah dilakukan perolehan data melalui kuesioner dan pada beberapa responden dilakukan wawancara. Tujuan dari perolehan data adalah untuk memperoleh informasi mengenai a). bagaimanakah sikap responden terhadap Pasal 200; b) bagaimakah pengaruh kultur hukum responden terhadap keputusan penggunaan (penegakan hukum) Pasal 200.

Kuesioner disusun berdasarkan pada kerangka teori tentang budaya hukum ibu menyusui sebagai salah satu factor penegakan hukum Pasal 200 yang telah dikemukakan pada bagian sebelumnya. Berikut adalah aspek-aspek terkait budaya hukum ibu menyusui dan representasinya dalam pertanyaan yang dibuat untuk memenuhi informasi terkait masing-masing aspek itu.

\begin{tabular}{|l|l|}
\hline $\begin{array}{l}\text { Aspek yang terkandung dalam } \\
\text { budaya hukum ibu menyusui }\end{array}$ & \multicolumn{1}{|c|}{$\begin{array}{c}\text { Representasi dalam alat penelitian (kuesioner, } \\
\text { wawancara) }\end{array}$} \\
\hline $\begin{array}{l}\text { nilai, pemikiran, sikap serta } \\
\text { harapan dari ibu menyusui atas }\end{array}$ & $\begin{array}{l}\text { a. pengetahuan responden tentang keberadaan Ps. } \\
200\end{array}$ \\
\hline
\end{tabular}




\begin{tabular}{|c|c|}
\hline Pasal 200 & $\begin{array}{l}\text { b.pengetahuan dan pemahaman responden tentang } \\
\text { sanksi pidana dalam Ps. } 200 \\
\text { c.pengetahuan dan pemahaman responden tentang } \\
\text { konsekuensi dari jenis sanksi pidana penjara dan } \\
\text { denda seperti yang ada dalam Ps. } 200 \\
\text { d. pendapat responden tentang Ps } 200 \text { tersebut } \\
\text { disertai alasannya (pertanyaan bersifat semi } \\
\text { terbuka) }\end{array}$ \\
\hline $\begin{array}{l}\text { kultur umum yang meliputi : } \\
\text { a. adat kebiasaan, opini, cara } \\
\text { bertindak dari ibu menyusui; } \\
\text { b. perilaku yang secara formal bisa } \\
\text { jadi merupakan hal yang } \\
\text { illegal, tetapi secara social } \\
\text { disetujui - } \\
\text { yang mengarahkan pada keputusan } \\
\text { untuk mengunakan atau tidak } \\
\text { menggunakan Pasal } 200\end{array}$ & $\begin{array}{l}\text { Keputusan responden, terkait dengan pelaporan } \\
\text { kepada polisi, beserta alasannya, apabila hak } \\
\text { menyusuinya (seperti dalam pasal } 128 \text { ayat 2) } \\
\text { dilanggar oleh pihak-pihak berikut: } \\
\text { a. pasangan } \\
\text { b. anggota keluarga selain pasangan } \\
\text { c. atasan di tempat kerja } \\
\text { d. rekan sejawat } \\
\text { Catatan: } \\
\text { - semua pertanyaan bersifat semi terbuka, dimana } \\
\text { responden dapat menuliskan alasan dari keputusan } \\
\text { yang telah dipilih } \\
\text { - alasan dari keputusan yang dipilih diharapkan dapat } \\
\text { menjawab apakah keputusan tersebut } \\
\text { (menggunakan atau tidak menggunakan Ps. 200) } \\
\text { dilatarbelakangi oleh hal-hal yang termasuk kultur } \\
\text { umum dari responden. }\end{array}$ \\
\hline
\end{tabular}

Responden berjumlah 62 orang dengan karakteristik;

a. ibu yang pernah memberikan ASI eksklusif selama minimal 3 bulan dan pernah mendapatkan informasi tentang manfaat pemberian ASI Eksklusif. Karakteristik ini dipilih karena pertanyaan dalam alat penelitian harus dijawab oleh responden yang telah mempunyai pengalaman memberikan ASI eksklusif pada bayinya. Sedangkan untuk karakteristik ibu yang pernah mendapatkan informasi tentang manfaat pemberian ASI Eksklusif' adalah penting karena berkaitan dengan alasan ibu untuk memberikan ASI eksklusif yang juga ditanyakan dalam alat penelitian.

b. ibu yang memenuhi kriteria pada huruf a dan berpendidikan minimal S1. Karakteristik ini dipilih karena diharapkan dengan pendidikan level tersebut responden adalah individu yang sadar akan hak-haknya sebagai warga negara pada umumnya dan sebagai ibu menyusui pada khsususnya.

\section{Budaya Hukum Ibu Menyusui dan Pengaruhnya pada Penegakan Hukum Pasal 200}

Untuk menjawab masalah penelitian terkait budaya hukum responden, Penulis menggunakan kuesioner dan wawancara pada beberapa responden. Semua responden yang berpartisipasi memenuhi karakteristik responden yang telah ditetapkan. Semua responden juga menjawab pernah mendapatkan informasi mengenai menfaat pemberian 
ASI eksklusif. Hal tersebut berkorelasi secara positif dengan jawaban semua responden yang menyatakan bahwa alasan memberikan ASI eksklusif pada bayinya adalah karena mengetahui manfaat pemberian ASI esklusif pada bayi. Semua responden memberikan ASI eksklusif pada tahun 2010 dan setelahnya. Hal ini penting mengingat Pasal 200 baru dilahirkan dalam UU Kesehatan yang diundangkan pada tahun 2009. Hal ini berpengaruh pada jawaban responden terkait pengetahuan responden mengenai keberadaan Pasal 200 itu sendiri. Lebih lanjut, sebagian besar responden adalah ibu menyusui yang berstatus karyawan (bekerja) pada saat pemberian ASI eksklusif. Fakta ini bermanfaat untuk mendapatkan gambaran terkait budaya hukum ibu menyusui dalam penegakkan Pasal 200 dalam konteks lingkungan tempat kerja.

Terkait dengan hasil temuan yang berhubungan dengan hal-hal yang dilindungi melalui ketentuan pidana Pasal 200, dijabarkan berikut ini. Dari jawaban dari semua responden, dukungan pasangan dan anggota keluarga dewasa dalam hal pemberian waktu yang merupakan hak yang dilindungi dalam Pasal 200, didapatkan oleh semua responden. Dengan kata lain, semua responden tidak mengalami masalah terkait dukungan dari pasangan dan anggota keluarga.

Kuesioner juga menyediakan pertanyaan khusus bagi responden yang bekerja pada saat masa pemberian ASI eksklusif. Pertanyaan didasarkan pada hak untuk diberikan waktu dan fasilitas khusus seperti telah dijelaskan pada Bab 2. Untuk pertanyaan ketersediaan ruang khusus untuk menyusui dan atau memerah ASI, dan apakah ruang tersebut memiliki meja dan kursi sebagai perlengkapan minimal yang harus dimiliki, sebagian besar responden menjawab tempat kerja mereka memilikinya, hanya 2 responden menjawab "tidak ada". Namun wawancara lanjutan yang dilakukan Penulis terhadap beberapa responden yang menjawab "ada" ternyata beberapa ruang khusus yang dimaksud adalah merupakan ruangan multifungsi yang memang dapat responden gunakan untuk memerah ASI. Ruangan dimaksud bukanlah ruangan khusus yang diperuntukkan dan dikhususkan bagi aktivitas menyusui atau memerah ASI. Selanjutnya untuk waktu khusus yang diberikan pengurus tempat kerja untuk memberikan ASI atau memerah ASI selama waktu bekerja di tempat kerja, hampir semua responden menjawab tidak disediakan waktu khusus. Walaupun demikian, semua responden juga menjawab bahwa tidak pernah mengalami diri responden dilarang untuk memerah ASI selama waktu kerja di tempat kerja. Sehingga Penulis menyimpulkan bahwa semua responden tidak pernah dilarang memerah ASI pada waktu kerja di tempat kerja walaupun pengurus tempat kerja tidak menyediakan ataupun mengatur waktu khusus untuk itu. Hal ini sejalan dengan jawaban semua responden yang bekerja bahwa sepengetahuan responden, tempat kerja responden tidak memiliki peraturan internal yang mengatur tentang pelaksanaan program ASI eksklusif ini. Lebih lanjut, semua responden yang bekerja juga menyatakan tdak pernah mengalami hal-hal berikut: i) memohon disediakan ruang khusus ASI namun ditolak/tidak diberikan, ii) memohon disediakan meja atau kursi di ruang khusus ASI namun ditolak/tidak diberikan.

Terkait dengan pengetahuan responden tentang Pasal 200, sebagian besar responden menjawab tidak mengetahui adanya ancaman sanksi pidana bagi pihak yang menghalangi program pemberian ASI eksklusif. Pada kuesioner, disediakan bunyi Pasal 200 dan Pasal 128 ayat (2) untuk dapat dibaca oleh responden. Selanjutnya Penulis 
menanyakan apakah responden memahami bahwa orang yang diberi sanksi pidana penjara berarti orang tersebut akan dikekang kebebasannya dan harus berada di dalam sel kurungan selama waktu tertentu. Atas pertanyaan ini semua responden menjawab mengetahui. Kuesioner juga menanyakan apakah responden mengetahui orang yang diberi sanksi pidana denda berarti orang tersebut harus membayar sejumlah uang yang ditentukan kepada negara dan bukan kepada korban kejahatannya. Atas pertanyaan ini cukup banyak responden menjawab tidak mengetahui/tidak memahami, walaupun sebagian lain responden menjawab memahami. Masih terkait dengan keberadaan Pasal 200 itu, hampir semua responden setuju dengan adanya Pasal 200 itu, namun dengan sedikit varian pada alasan yang diberikan. Secara garis besar alasannya antara lain:

a. setuju karena aturan itu dipandang dapat mendukung keberhasilan program ASI eksklusif dan meningkatkan kualitas anak Indonesia

b. untuk memberi perlindungan kondisi yang mendukung bagi ibu menyusui

c. karena merupakan hak setiap ibu untuk memberikan yang terbaik untuk anaknya dan hak setiap anak untuk mendapatkan ASI.

Selain itu, terdapat sejumlah kecil responden yang menjawab tidak menyetujui aturan Pasal 200 dengan alasan:

a. bahwa hak menyusui adalah hak istimewa ibu dan tidak ada kaitannya dengan orang lain

b. bahwa sanksi penjara terlalu berlebihan

Dalam rangka mengetahui budaya hukum responden, ditanyakan hal-hal sebagai berikut:

a. Apabila pasangan responden dengan sengaja menghalangi responden dalam memberikan ASI Eksklusif, apakah responden akan melaporkan pasangan responden ke pihak kepolisian

b. Apabila anggota keluarga dewasa responden (selain pasangan) dengan sengaja menghalangi responden dalam memberikan ASI Eksklusif, apakah responden akan melaporkan anggota keluarga tersebut ke pihak kepolisian.

c. Apabila atasan di tempat kerja responden dengan sengaja menghalangi responden dalam memberikan ASI Eksklusif, apakah responden akan melaporkan atasan responden tersebut ke pihak kepolisian

d. Apabila anggota rekan sejawat responden dengan sengaja menghalangi responden dalam memberikan ASI Eksklusif, apakah responden akan melaporkan rekan sejawat tersebut ke pihak kepolisian

Semua responden menjawab tidak akan melaporkan kepada pihak kepolisian apabila pasangan responden yang menghalangi pemberian ASI eksklusif. Alasan yang diberikan antara lain sebagai berikut:

a. responden membutuhkan pasangannya terutama untuk membesarkan anak-anak, responden berpendapat kalau pasangannya dipenjara maka tidak ada yang membantunya.

b. responden tidak mau rumah tangga responden dan pasangan berantakan (rusaknya rumah tangga responden dengan pasangan). 
c. responden merasa memiliki ketergantungan pada pasangan karena responden tidak bekerja.

d. responden kasihan karena menurut responden bisa saja itu terjadi karena pasangan kurang memahami tentang ASI ekslusif

e. bila pasangaan dilaporkan maka akan menimbulkan dampak yang merugikan responden sendiri

f. menempuh memberikan penjelasan dulu pada pasangan

a. Untuk pelanggaran yang dilakukan oleh anggota keluarga dewasa lain pun semua responden menjawab tidak akan melaporkan ke polisi dengan alasan berikut:

a. responden merasa masih bisa diselesaikan dengan cara musyawarah/kekeluargaan/baik-baik

b. responden memilih untuk memberikan pengetahuan tentang ASI pada anggota keluarga

c. responden tidak mau merusak hubungan keluarga

d. menurut responden keputusan memberikan ASI seharusnya tergantung pada sikap dan keputusan si ibu bukan orang lain.

e. menurut responden hal itu hanya akan mempersulit diri responden sendiri

Sedangkan untuk pertanyaan apabila yang menghalangi adalah atasan ataupun rekan kerja ataupun pengurus tempat kerja, sebagian besar responden juga menjawab tidak akan melaporkan ke pihak kepolisian, walaupun ada sebagian kecil responden yang menjawab tidak tahu. Namun, tidak ada satupun responden yang menjawab akan melaporkan ke pihak kepolisian. Adapun alasan bagi yang menjawab tidak akan melaporkan antara lain adalah sebagai berikut:

a. responden memilih menyelesaikan secara internal atau kekeluargaan

b. menurut responden adalah hak setiap orang untuk berpendapat (termasuk pendapat untuk tidak mendukung pemberian ASI)

c. responden memilih menyampaikan sikapnya sendiri, termasuk tentang hak nya tentangASI tanpa melibatkan polisi

d. responden memilih mencari bantuan kepada organisasi terkait ASI seperti AIMI (Asosiasi Ibu Menyusui Indonesia).

e. responden memilih memberikan pengetahuan dan penjelasan dulu.

Untuk sebagian kecil responden yang menjawab "tidak tahu", berikut alasan yang diberikan:

a. karena bukan keluarga/pasangan. Sebagai catatan, responden yang memberikan alasan ini menjawab tidak akan melaporkan ke polisi apabila pasangan atau keluarga yang menghalangi pemberian ASI.

b. responden akan melihat kondisi dulu

Sebagai catatan, dari 62 kuesioner yang dikembalikan, terdapat sekitar 5 kuesioner yang jawaban terhadap bagian yang menanyakan keputusan penggunaan Pasal 200 tidak dapat dipakai, karena alasan yang diberikan tidak menjawab pertanyaannya. Dari jawaban responden seperti yang dikemukakan di atas, terlihat bahwa walaupum hampir semua responden menyetujui adanya Pasal 200 namun hampir semua responden memilih untuk tidak menggunakannya. Hal tersebut didasarkan pada alasan-alasan yang sebagian besar masuk dalam kategori kultur umum dalam kerangka budaya hukum dari responden. 
Walaupun terdapat juga alasan yang tidak dapat secara tegas dikatakan merupakan kultur umum. Kultur umum yang terepresentasi dalam jawaban antara lain ada dalam kategori opini dan juga cara bertindak dari ibu menyusui. Yang masuk dalam kategori opini adalah alasan- alasan seperti ; responden kasihan karena menurut responden bisa saja itu terjadi karena pasangan kurang memahami tentang ASI ekslusif, bila pasangaan dilaporkan maka akan menimbulkan dampak yang merugikan responden sendiri, menurut responden keputusan memberikan ASI seharusnya tergantung pada sikap dan keputusan si ibu bukan orang lain, menurut responden melaporkan anggota keluarga hanya akan mempersulit diri responden sendiri dan menurut responden adalah hak setiap orang untuk berpendapat (termasuk pendapat untuk tidak mendukung pemberian ASI).

Sedangkan alasan yang termasuk cara bertindak dari responden adalah : menempuh memberikan penjelasan tentang ASI dan hak menyusui baik bagi pasangan, anggota keluarga, atasan maupun rekan sejawat; responden merasa masih bisa diselesaikan dengan cara musyawarah/kekeluargaan/baik-baik baik dalam lingkup internal keluarga maupun tempat kerja; responden tidak mau merusak hubungan keluarga; dan responden memilih mencari bantuan kepada organisasi terkait ASI seperti AIMI (Asosiasi Ibu Menyusui Indonesia). Sedangkan hal lain yang muncul sebagai alasan dari responden yang tidak dapat secara tegas dikategorikan dalam kelompok opini ataupun cara bertindak, sebagian besar adalah berupa resiko yang dipikirkan (ditakutkan) oleh responden dapat terjadi apabila responden memilih menggunakan Pasal 200. Alasan tersebut misalnya ketakutan rusaknya hubungan dengan pasangan atau anggota keluarga dan kesadaran responden akan ketergantungannya secara ekonomis pada pasangan.

Terkait dengan masalah dalam penelitian ini maka terlihat bahwa budaya hukum yang berisi kultur umum dari ibu menyusui yang terepresentasi melalui alasan-alasan yang ditemukan dalam penelitian ini menjadi factor yang menyebabkan ibu menyusui memilih untuk tidak melaporkan pada polisi (tidak menggunakan ketentuan pidana dalam Pasal 200) atas pelanggaran hak menyusui nya. Hal ini sekaligus menjelaskan bahwa budaya hukum ibu menyusui merupakan salah satu sebab mengapa penegakan dari Pasal 200 belum terlaksana. Hal ini juga sangat berkaitan dengan sifat dan kondisi dari pelanggaran hak menyusui tersebut, terutama bila terjadi dalam lingkungan keluarga dan juga pada lingkungan tempat kerja, yang sedemikian rupa sehingga sulit apabila tidak ada pelaporan dari ibu menyusui ataupun minimal kesediaan dari ibu menyusui untuk terlibat dalam proses penegakkan hukum pidananya, seperti telah dijelaskan pada bagian sebelumnya. Apabila hal itu dikaitkan dengan sikap ibu menyusui yang sudah terjawab melalui hasil temuan yang telah dideskripsikan di atas, maka dapat dikatakan bahwa walaupun semua responden mempuyai sikap menyetujui apa yang diatur dalam Pasal 200 juncto Pasal 128 ayat (2), dengan berbagai alasan yang melatarbelakanginya, namun hal tersebut tidak membuat responden memilih untuk menggunakan Pasal 200.

\section{Penutup}

Menurut hasil temuan dalam penelitian ini, salah satu factor yang menyebabkan penegakan hukum pasal 200 UU No. 36 Tahun 2009 belum berjalan adalah karena budaya hukum ibu menyusui yang menjadi responden masih belum mendukung terlaksananya penegakan hukum dimaksud. Budaya hukum tersebut berisi kultur umum yang merupakan 
alasan responden ibu menyusui memilih untuk menempuh cara lain dalam menghadapi situasi dan kondisi apabila hak-hak menyusuinya terlanggar, dan tidak memilih cara menggunakan Pasal 200. Sedangkan, peran dari ibu menyusui dalam penegakkan hukum Pasal 200 amatlah essential. Hal ini dikarenakan perbuatan pidana seperti dimaksud dalam Pasal 200 bersifat sedemikian rupa sehingga tanpa keterlibatan ibu menyusui dalam pelaporan ataupun bentuk keterlibatan lainnya membuat penegakan hukum Pasal 200 sulit dilakukan. Sehingga, sesuai dengan beberapa teori tentang penegakan hukum seperti telah dikemukakan, budaya hukum responden ibu menyusui yang merupakan salah satu elemen penting dalam penegakan hukum, dalam penelitian ini ternyata tidak mendukung penegakan hukum dari Pasal 200. Lebih lanjut, apabila dikaitkan dengan sikap responden ibu menyusui terhadap Pasal 200, data menunjukkan bahwa hampir semua responden menyetujui apa yang diatur alam Pasal 200 tersebut.

Namun sikap tersebut tidak membuat responden memilih menggunakan Pasal 200 sebagai respon apabila hak menyusuinya dilanggar oleh pasangan, keluarga atau pihak dalam lingkup lingkungan bekerja. Namun demikian, perlu dicatat bahwa penelitian ini tidak sampai pada kesimpulan terkait manfaat Pasal 200 bagi perlindungan pemberian ASI eksklusif, dikarenakan hal tersebut tidak termasuk dalam lingkup masalah yang diteliti. Sehingga, hasil temuan dan kesimpulan pada penelitian ini yang membuktikan bahwa budaya hukum responden ibu menyusui yang diteliti adalah salah satu factor tidak terjadinya penegakan hukum, tidak dapat dijadikan dasar untuk menarik sebuah asumsi bahwa Pasal 200 tidak memberikan manfaat perlindungan ataupun manfaat lainnya bagi program ASI eksklusif. Menurut Penulis, perlu diadakan penelitian tersendiri untuk melakukan asesmen terhadap fungsi dan manfaat dari Pasal 200 bagi pelaksaan program ASI eksklusif

\section{Daftar Pustaka}

\section{Buku}

Adi, Rianto, Metode Penelitian Sosial dan Hukum, Granit, Jakarta, 2004.

Friedman, Lawrence M, Sistem Hukum; Perspektif Ilmu Sosial (The Legal System; A Social Science Perspective), Nusa Media, Bandung, 2015

Handajani ES, Sri Pola Pemberian dan Komposisi Gizi ASI, Bengkel Buku, Yogyakarta, 2002

Kasiram, H. Moh. Kasiram, Metodologi Penelitian Kualitatif-Kuantitaif, UIN Maliki Press, Malang, 2010.

Kelsen, Hans, Teori Umum Tentang Hak dan Negara, Nusa Media, Bandung, 2011

Rahardjo, Satjipto, Penegakan Hukum-Suatu Tinjauan Sosiologis, Genta Publishing, Yogyakarta, 2009 
Safa'at, Muchamaad Ali, Konsep Hukum HL.A Hart, Konstitusi Pers, Jakarta, 2016

\section{Artikel Jurnal}

Harkrisnowo, Harkristuti, "Menjalani Masa Transisi-Mungkinkah Hukum Sebagai Panglima", Jurnal Studi Indonesia, Vol 10 No. 1, 2000

Kadir, Nurhira Abdul, "Menelusuri Akar Masalah Rendahnya Persentase Pemberian ASI Ekslusif di Indonesia", Jurnal Al Hikmah Vol XV No. 1, 2014

\section{Hasil Penelitian/Tugas Akhir}

Ridzal, Debi Silvia Ridzal, 2016, Perspektif Kebijakan Hukum Pidana Terhadap Pelaksanaan Program ASI Eksklusif (Studi di Wilayah Hukum Polda Lampung), http://digilib.unila.ac.id

\section{Makalah/Pidato}

Asshiddiqie, Jimly, "Pembangunan Hukum Dan Penegakan Hukum Di Indonesia", Makalah, Seminar "Menyoal Moral Penegak Hukum" dalam rangka Lustrum XI Fakultas Hukum Universitas Gadjah Mada, Yogyakarta, 17 Februari 2006.

Saleh, Sudibyo, "Komitmen Supremasi Hukum di tengah Kemajuan Masyarakat Indonesia", Makalah, Dialog Nasional Profesional Aparat Penegak Hukum dalam Pelaksanaan di tengah Masyarakat yang Bersih dan Berwibawa, Jakarta, 11 Oktober 2004

\section{Artikel Majalah/Koran}

Ujan, Andre Ata, "Membangun Budaya Hukum", Law Enfrocement and Jusctice Magazine, Vol 20 Tahun 2012

\section{Internet}

IDAI, "Suskes Menyusui Saat Bekerja", http://idai.or.id/publicarticles/klinik/asi/sukses-menyusui-saat-bekerja-2.html, diakses pada $10 \mathrm{Mei}$ 2017

https://thelawdictionary.org/habeas-corpus/

\section{Peraturan Perundang-Undangan}


Undang-Undang Nomor 36 Tahun 2009 Tentang Kesehatan (Lembaran Negara Republik Indonesia Tahun 2009 Nomor 144, Tambahan Lembaran Negara Republik Indonesia Nomor 50635063)

Peraturan Pemerintah Nomor 33 Tahun 2012 Tentang Pemberian ASI Eksklusif (Lembaran Negara Republik Indonesia Tahun 2012 Nomor 58, Tambahan Lembaran Negara Republik Indonesia Nomor 5291)

Peraturan Menteri Kesehatan Nomor 15 Tahun 2013 Tentang Tata Cara Penyediaan Fasilitas Khusus Menyusui dan/atau Memerah Air Susu Ibu (Berita Negara Republik Indonesia Tahun 2013 Nomor 441) 